\title{
STUDI LOKASI RAWAN KECELAKAAN DI KOTA BANDUNG
}

\author{
Rizki Mirzam Nuryasan ${ }^{1}$, Budi Hartanto Susilo ${ }^{2}$ \\ ${ }^{1}$ Alumni, Program Studi Teknik Sipil, Fakultas Teknik, Universitas Kristen Maranatha \\ ${ }^{2}$ Guru Besar, Program Studi Teknik Sipil, Fakultas Teknik, Universitas Kristen Maranatha \\ Email:rmirzam@gmail.com, budiharsus@yahoo.com
}

\begin{abstract}
ABSTRAK
Kecelakaan lalu lintas menjadi permasalahan utama dalam penyelanggaraan tranportasi jalan di Indonesia. Untuk meningkatkan keselamatan transportasi jalan ada beberapa cara salah satunya yaitu melakukan penentuan dan penanganan lokasi rawan kecelakaan (LRK). Tujuan dari penelitian ini adalah menentukan, menganalisis dan menyusun penanganan LRK dengan metode Angka Ekuivalen Kecelakaan (AEK) dan Upper Control Limit (UCL). Studi ini menggunakan data sekunder dari Polrestabes Bandung (periode tahun 2018). Dalam analisis frekuensi kecelakaan, terdapat 92 LRK, kemudian analisis dengan metode AEK dan UCL menghasilkan 15 LRK prioritas. Dari identifikasi LRK prioritas digunakan 3 (tiga) LRK prioritas untuk menjadi acuan dalam melakukan survei lapangan, pembuatan denah LRK dan usulan tindakan penanganan LRK yaitu Jalan Sor GBLA, Jalan Soekarno-Hatta, dan Simpang SupratmanCiliwung.
\end{abstract}

Kata kunci: Lokasi Rawan Kecelakaan, AEK, UCL

\begin{abstract}
Traffic accidents are a major problem in managing road transportation in Indonesia. To improve road transportation safety, there are several ways, one of which is determining and handling accident-prone locations (LRK). The purpose of this study is to determine, analyze and arrange LRK handling with the Accident Equivalent Number (AEK) and Upper Control Limit (UCL) methods. This study uses secondary data from Bandung Polrestabes (period 2018). In the analysis of accident frequencies, there were 92 LRKs, then analysed using the AEK and UCL methods resulted in 15 priority LRKs. From the identification of priority LRKs, 3 (three) priority LRKs are used as a reference in conducting field surveys, making LRK plans and proposing LRK handling actions, namely the Sor GBLA Road, SoekarnoHatta Road, and Supratman-Ciliwung Junction.
\end{abstract}

Keywords: Accident Prone Locations, AEK, UCL

\section{PENDAHULUAN}

Salah satu permasalahan lalu lintas yang sangat mengkhawatirkan adalah kecelakaan lalu lintas. Ada empat faktor penyebab kecelakaan lalu lintas yaitu; manusia, kendaraan, sarana dan prasarana, serta cuaca. Kecelakaan lalu lintas merupakan penyebab kematian terbesar di dunia menurut World Health Organization (WHO), 2015. Jumlah korban yang cukup besar memberikan dampak ekonomi (kerugian materil) dan sosial. Badan Pusat Statistik (BPS) Kota Bandung tahun 2017 menyatakan Kota Bandung memiiki populasi penduduk sebesar 2.497.938 jiwa, dengan luas wilayah 167,31 km² jumlah Potensi Kendaraan Bermotor sebesar 1.881.498 (KBM) dan yang menjadi sorotan dengan jumlah korban kematian akibat kecelakaan lalu lintas sebesar 150 jiwa yang tercantum pada Integrated Road Safety Management System (IRSMS) KORLANTAS, 2018. Permasalahan kecelakaan lalu lintas ini memerlukan suatu penelitian 
sebagai upaya untuk mengungkap dan mengidentifikasi faktor-faktor penyebab kecelakaan lalu lintas. Tujuan dari penelitian ini adalah menentukan, menganalisis dan menyusun penanganan LRK di Kota Bandung dengan metode Angka Ekuivalen Kecelakaan (AEK) dan Upper Control Limit (UCL).

\section{TINJAUAN PUSTAKA}

\subsection{Kecelakaan dan Lokasi Rawan Kecelakaan}

UU RI No. 22 tahun 2009 menyatakan pada pasal 1 (24) bahwa Kecelakaan Lalu Lintas adalah suatu peristiwa di Jalan yang tidak diduga dan tidak disengaja melibatan Kendaraan dengan atau tanpa Pengguna Jalan lain yang mengkibatkan korban manusia dan/atau kerugian harta benda. Pada pasal 203 (1) tercantum bahwa Pemerintah bertanggung jawab atas terjaminnya Keselamatan Lalu Lintas dan Angkutan Jalan.

Berdasarkan Pd T-09-2004-B, Departemen Pemukiman dan Prasarana Wilayah (Puslitbang PU), 2004, Lokasi Rawan Kecelakaan (LRK) adalah suatu lokasi di mana angka kecelakaan tinggi dengan kejadian kecelakaan berulang dalam suatu ruang dan rentang waktu yang relatif sama yang diakibatkan oleh suatu penyebab tertentu. Artinya identifikasi Lokasi Rawan Kecelakaan dilakukan dengan mencari lokasi (persimpangan, jembatan, dan ruas jalan sepanjang $300 \mathrm{~m}$ ) di mana terjadi kecelakaan lalu lintas $\geq 2$ kali dalam 1 tahun.

\subsection{Pemeringkatan LRK dengan Metode Analisis Angka Ekuivalen Kecelakaan}

Pemeringkatan LRK dengan menggunakan metode Angka Ekivalen Kecelakaan (AEK). AEK adalah skala ekonomi numerik untuk menimbang tingkat kecelakaan berdasarkan keparahan korbannya, AEK tercantum pada Departemen Pemukiman dan Prasarana Wilayah, 2004. Pada Persamaan 2.1 digunakan rumus AEK.

$\mathrm{AEK}=100 \mathrm{MD}+20 \mathrm{LB}+5 \mathrm{LR}+1 \mathrm{KM}$

dengan:

MD = Meninggal dunia

LB = Luka berat

LR = Luka Ringan

$\mathrm{KM}=$ Kerugian materi

Penentuan Prioritas Lokasi Rawan Kecelakaan menggunakan statistik kendali mutu sebagai control-chart UCL (Upper Control Limit). Segmen ruas jalan dengan tingkat kecelakaan yang berada di atas garis UCL didefinisikan sebagai lokasi rawan kecelakaan. Rumus UCL sebagaimana Persamaan 2.2:

Studi Lokasi Rawan Kecelakaan di Kota Bandung 
$\mathrm{UCL}=\lambda+[\sqrt{ } 2,576(\lambda /(\mathrm{m}))]+[0,829 /(\mathrm{m})]+[1 / 2(\mathrm{~m})]$

dengan:

$\mathrm{UCL}=$ garis kendali batas atas

$\lambda \quad=$ rata-rata tingkat kecelakaan dalam satuan kecelakaan per eksposure

$\mathrm{m} \quad=$ satuan eksposure, $\mathrm{km}$

\subsection{Diagram Tabrakan}

Diagram tabrakan adalah suatu desain penggambaran atau visualisasi terhadap kecelakaan lalu lintas yang terjadi di lokasi. Kecelakaan berdasarkan jenis, penyebab, kondisi jalan saat terjadi kecelakaan.

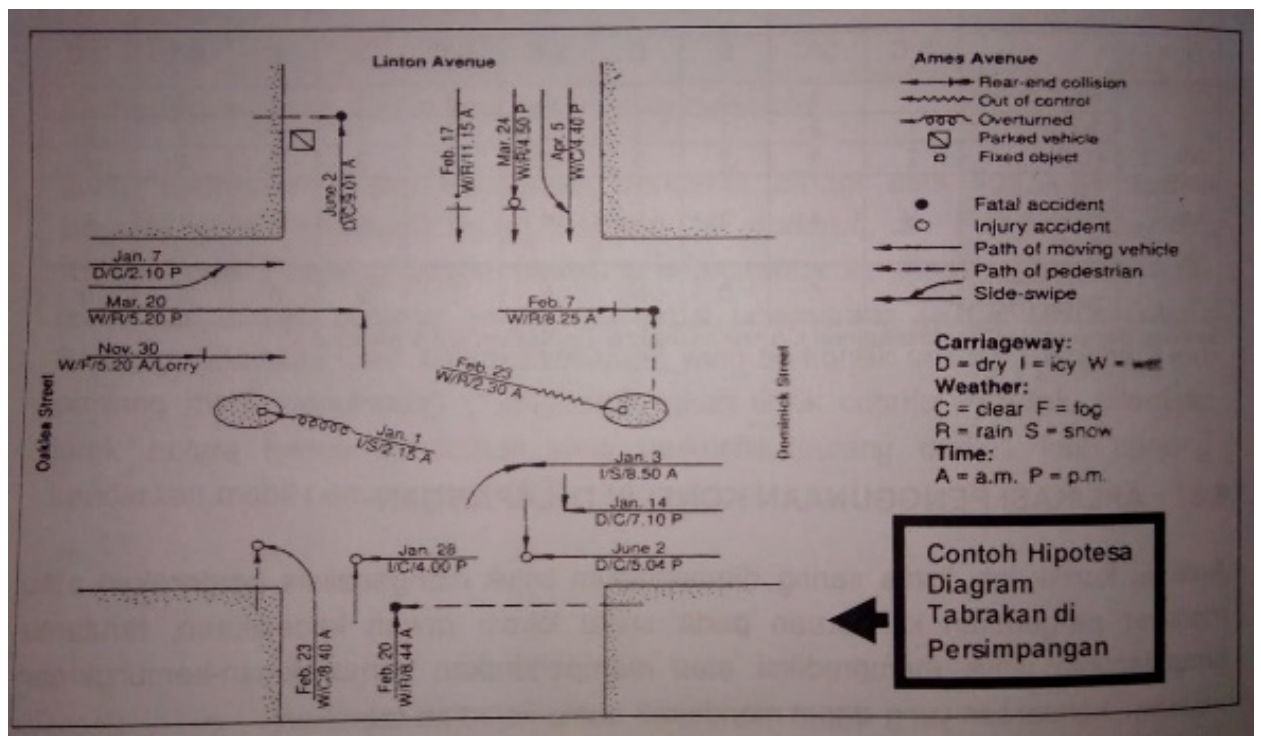

Gambar 1. Diagram Tabrakan (Susilo, 2016)

\subsection{Penanganan LRK}

Menurut Pedoman Penanganan Lokasi Rawan Kecelakaan Lalu Lintas (Pd T-09-2004-B, Puslitbang PU, 2004), disebutkan prinsip dasar penanganan lokasi rawan kecelakaan antara lain:

1. Penanganan lokasi rawan kecelakaan sangat bergantung kepada akurasi data kecelakaan, karenanya data yang digunakan untuk upaya ini harus bersumber pada instansi resmi;

2. Penanganan harus dapat mengurangi angka dan korban kecelakaan semaksimal mungkin pada lokasi kecelakaan;

3. Solusi penanganan kecelakaan dipilih berdasarkan pertimbangan tingkat pengurangan kecelakaan dan pertimbangan ekonomis; 


\section{METODOLOGI}

\subsection{Lokasi Penelitian}

Lokasi penelitian ini berletak di wilayah Kota Bandung, Jawa Barat. Penentuan letak lokasi penelitian yang akan digunakan sebagai acuan survei lapangan didapatkan melalui klasifikasi LRK dan analisis dengan metode AEK dan UCL.

\subsection{Pengumpulan Data}

Data penelitian terdiri dari data primer dan data sekunder, data primer meliputi data eksisting survei lapangan dan data mapping.

1. Eksisting survei lapangan

Data yang dikumpulkan dari hasil, survei geometri, survei kecepatan, survei fasilitas perlengkapan jalan.

2. Data mapping

Data mapping merupakan data yang dikumpulkan dari Google My Maps.

Data sekunder merupakan data kecelakaan lalu lintas tahun 2018 yang diperoleh dari survei instansi (Polrestabes Bandung).

Proses pengambilan data penelitian dilakukan pada tanggal 23 April 2019 dan dimulai pukul 09.00-17.00 WIB. Pada setiap lokasi survei dilakukan survei geometri, survei kecepatan dan survei fasilitas perlengkapan jalan. Adapun langkah-langkah pelaksanaan survei di lapangan yaitu:

1. Survei geometri jalan

a) Survei geometri dilakukan dengan cara mengukur dimensi badan jalan, bahu jalan, kerb/trotoar. Pengukuran menggunakan meteran rol yang telah disiapkan.

b) Orang pertama bertugas memegang meteran rol di titik A dan mencatat ukuran yang diperoleh.

c) Orang kedua bertugas untuk menarik meteran rol ke titik B.

2. Survei kecepatan

Survei kecepatan dilakukan dengan cara menghitung waktu tempuh yang dibutuhkan kendaraan untuk mencapai jarak yang telah ditetentukan. Pengambilan data kecepatan dilakukan di setiap ruas jalan yang ditinjau, jarak ditentukan dari titik A ke B sejauh 50m dan jumlah sampel yang diambil sebanyak 40 kendaraan bermotor.

Studi Lokasi Rawan Kecelakaan di Kota Bandung 
3. Survei fasilitas perlengkapan jalan

Survei fasilitas perlengkapan jalan dilakukan dengan menyusuri serta mengamati ruas jalan yang ditinjau sepanjang $300 \mathrm{~m}$ atau area yang ditinjau kemudian mendata setiap fasilitas perlengkapan jalan, meliputi; rambu-rambu lalu lintas, lampu penerangan jalan, marka jalan, dan lain-lain.

\subsection{Diagram Alir Penelitian}

Diagram alir penelitan ditunjukkan pada Gambar 2.

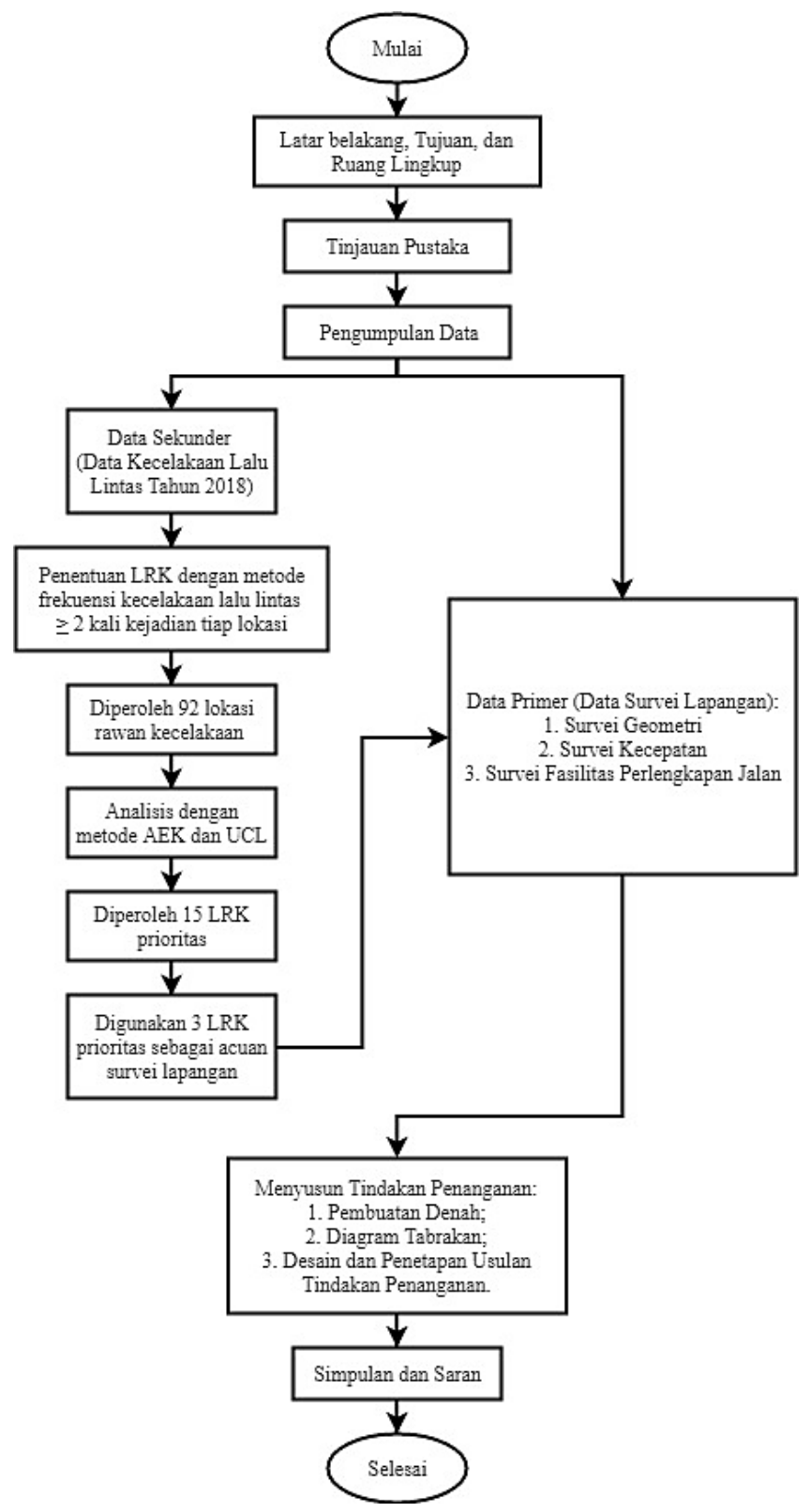

Gambar 2. Diagram Alir Metode Penelitian 


\section{HASIL DAN DISKUSI}

Data sekunder kecelakaan lalu lintas yang diperoleh dari data Polrestabes Bandung pada periode tahun 2018. Data tersebut menyatakan sebanyak 499 kejadian yang tersebar di seluruh jaringan jalan Kota Bandung. Dari 499 kecelakaan lalu lintas tersebut melalui analisis terklasifikasi LRK sebanyak 92 lokasi yang dikategorikan sebagai lokasi rawan kecelakaan dengan jumlah kecelakaan lebih besar sama dengan 2 (jumlah kejadian $\geq 2$ ), sebagaimana ada pada Gambar 3 dapat dilihat pemetaan 499 lokasi kejadian.

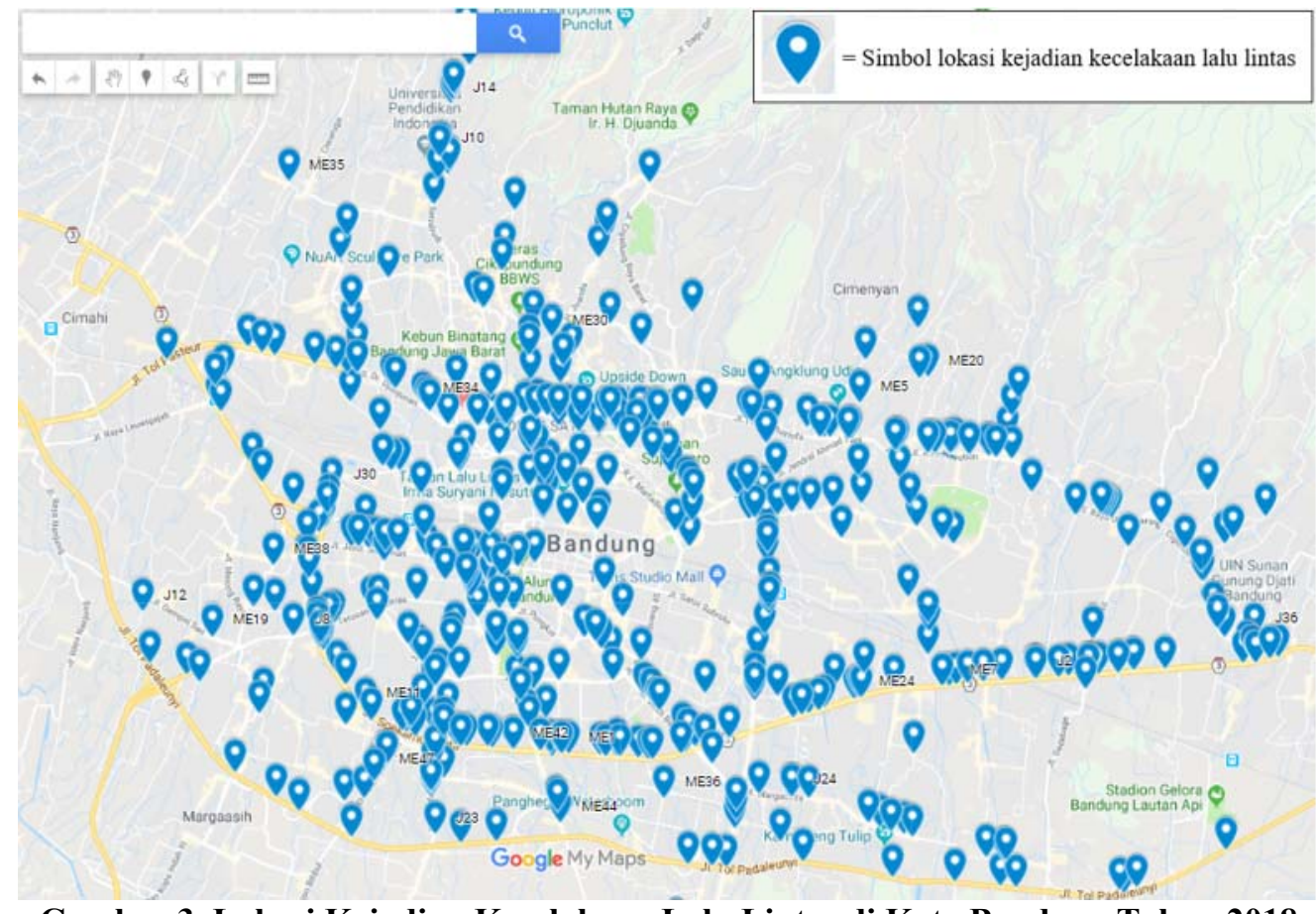

Gambar 3. Lokasi Kejadian Kecelakaan Lalu Lintas di Kota Bandung Tahun 2018

\subsection{Analisis AEK dan UCL}

Dari 92 LRK dilakukan analisis dengan AEK dan UCL sehingga menghasilkan 15 LRK prioritas. Data tersebut dapat dilihat pada Gambar 5 yang merupakan kurva antara nilai AEK dan UCL di setiap lokasi. Daftar 15 LRK prioritas ditunjukkan pada Tabel 1.

Dari 15 LRK tersebut, digunakan 3 (tiga) LRK sebagai prioritas penanganan pada penelitian ini. 3 (tiga) lokasi tersebut dipilih untuk dilakukan survei lapangan data eksisting. LRK prioritas terpilih ditentukan melalui beberapa pertimbangan, antara lain berdasarkan peringkat AEK dan nilai UCL, variasi ruas jalan dan simpang. Untuk letak lokasi survei lapangan dapat dilihat pada Gambar 5. 


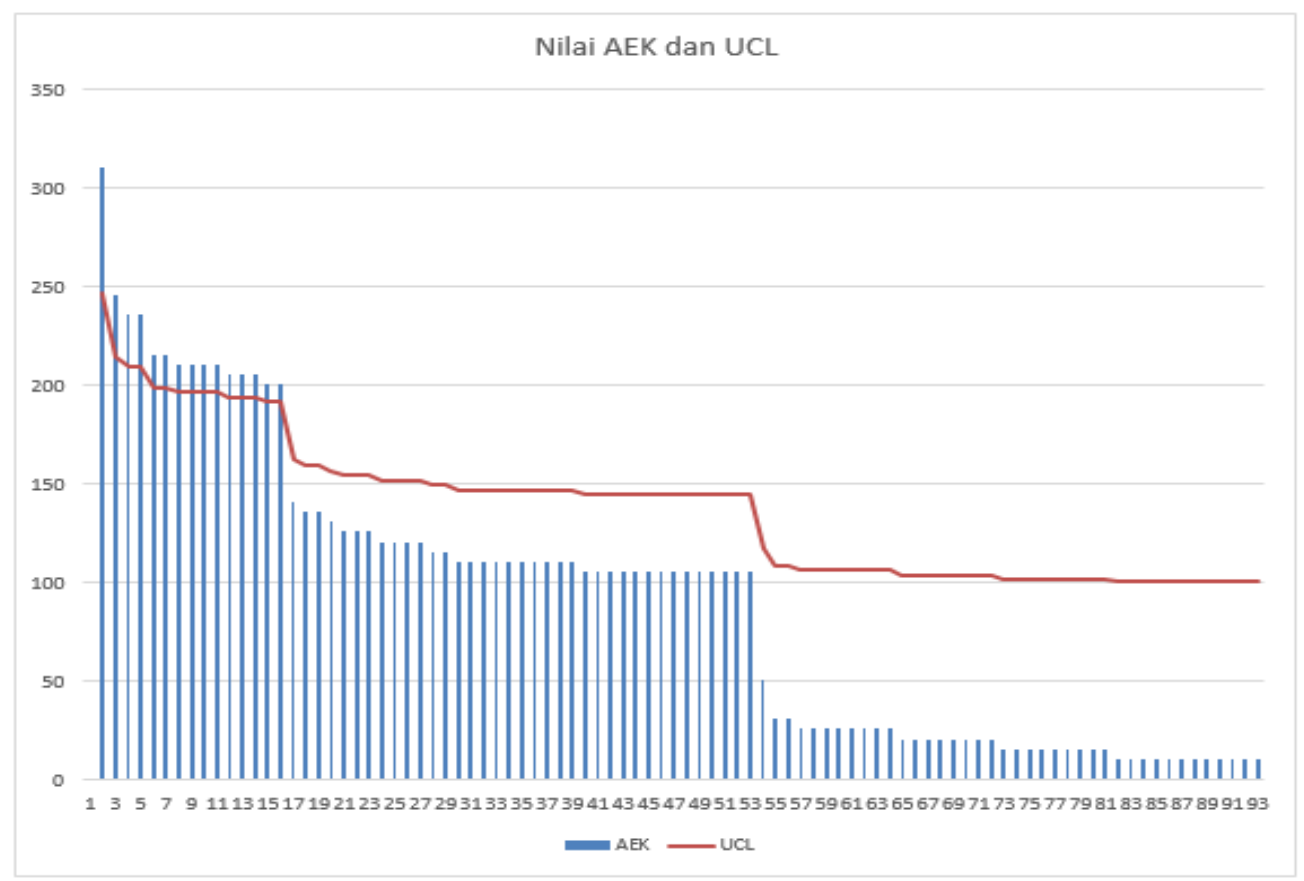

Gambar 4. Kurva Nilai AEK dan UCL pada 92 Lokasi LRK

Tabel 1. Analisis AEK dan UCL

\begin{tabular}{|c|c|c|c|c|c|c|}
\hline \multirow[b]{2}{*}{ No. } & \multirow[b]{2}{*}{ Lokasi } & \multicolumn{3}{|c|}{ Korban } & \multirow[b]{2}{*}{ AEK } & \multirow[b]{2}{*}{ UCL } \\
\hline & & JK & MD LB & $\overline{\mathrm{LR}}$ & & \\
\hline 1 & $\begin{array}{l}\text { JL. Sor Pendamping Depan } \\
\text { Pesawahan Kec, Gedebate }\end{array}$ & 3 & $\frac{1}{2}$ & 3 & 311 & 246,82 \\
\hline 2 & $\begin{array}{l}\text { Ji. Ah Nasution (Depan } \\
\text { Cell Phone Store Fitri } \\
\text { Mandiri) Bdg }\end{array}$ & 2 & 2 & 2 & 246 & 214,43 \\
\hline 3 & $\begin{array}{l}\text { ת. Ahmad Yani No. } 416 \\
\text { Bdr }\end{array}$ & 3 & 2 & 2 & 236 & 209,45 \\
\hline 4 & $\begin{array}{l}\text { ת. Ah. Nasution Dpa No. } \\
57 \mathrm{Bdg}\end{array}$ & 3 & 2 & 2 & 236 & 209,45 \\
\hline 5 & $\begin{array}{l}\text { Л. Ibrahim Adjie No. } 119 \\
\text { Bdg Atm Bask Bet }\end{array}$ & 4 & 2 & 2 & 216 & 199,5 \\
\hline 6 & $\begin{array}{l}\text { I. Soekamo Hatta Dpn } \\
\text { STIMIK Jaber Bdg }\end{array}$ & 3 & 2 & 2 & 216 & 199,5 \\
\hline 7 & $\begin{array}{l}\text { J. Dr.Setrabudh Dpn No. } \\
\text { 293-295 Bdg }\end{array}$ & 4 & 2 & 2 & 211 & 797,01 \\
\hline 8 & $\begin{array}{l}\text { J. Jendral Sudimman No. } \\
55 \mathrm{Bdg}\end{array}$ & 3 & 2 & 2 & 211 & 197,01 \\
\hline 9 & $\begin{array}{l}\text { J. Soekarno Hatta Dpn } \\
\text { No.145 Bdg }\end{array}$ & 3 & 2 & 2 & 211 & 197,01 \\
\hline 10 & $\begin{array}{l}\text { Л. Soekamo Hatta No. } \\
400 \text { Bdg }\end{array}$ & 2 & 2 & 1 & 211 & 197,01 \\
\hline 11 & $\begin{array}{l}\text { Л. Ciliwung - Jl. } \\
\text { Supratman Bdg (Simpane) }\end{array}$ & 2 & 2 & 1 & 206 & 194,52 \\
\hline 12 & $\begin{array}{l}\text { II Soekamo Fatta Depar } \\
\text { Fm. Cibiuk }\end{array}$ & 2 & 2 & $T$ & 200 & 794,52 \\
\hline 13 & $\begin{array}{l}\text { J. Phh. Mustofa Dpn } \\
\text { Kantor Pln No. } 45 \text { Bdg }\end{array}$ & 2 & 2 & 1 & 206 & 194,52 \\
\hline 14 & $\begin{array}{l}\text { Л. Terusan Jakarta Dpn } \\
\text { No. } 37 \text { Bdg }\end{array}$ & 2 & 2 & & 201 & 192,04 \\
\hline 15 & $\begin{array}{l}\text { Tol Purbaleunyi Km. } \\
144+900\end{array}$ & 2 & 2 & & 201 & 192,04 \\
\hline
\end{tabular}




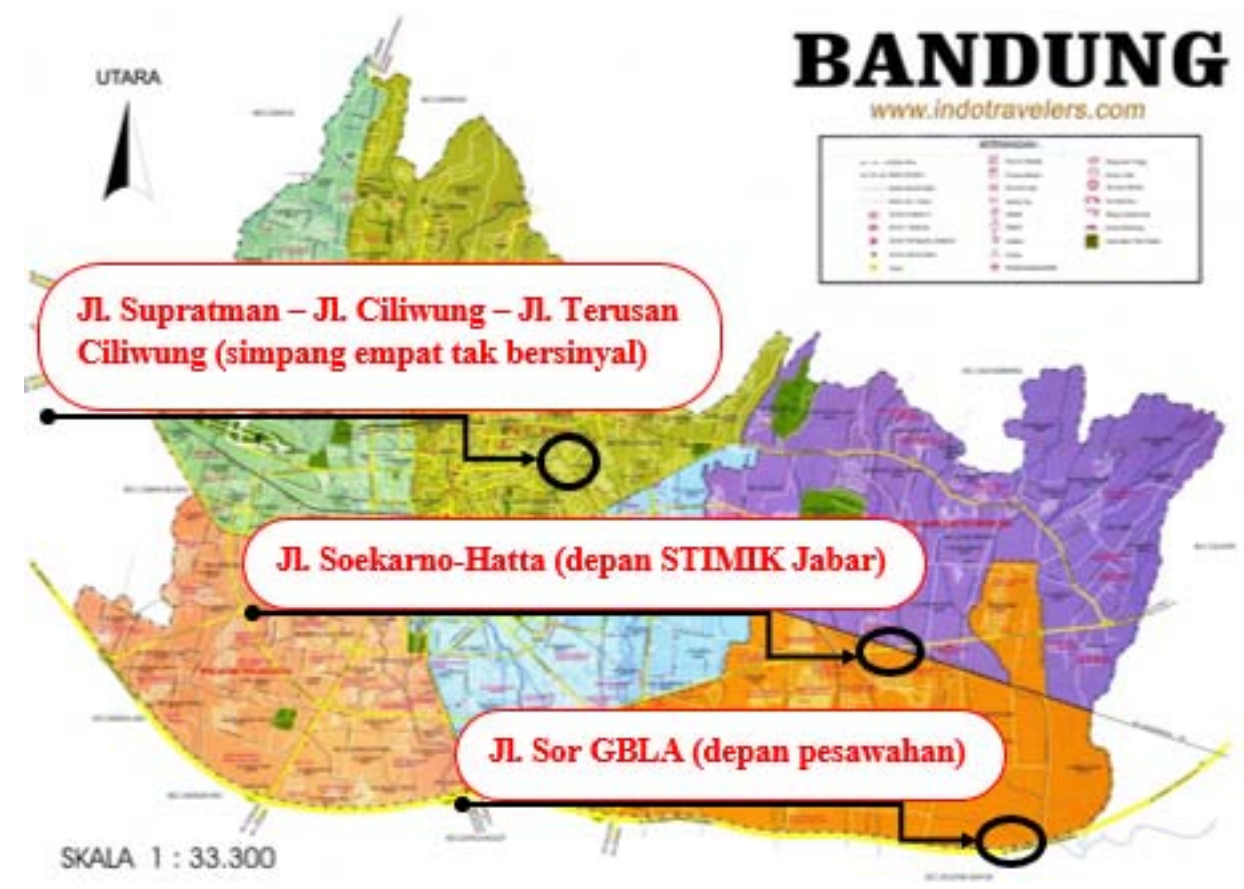

Gambar 5. Peta LRK Terpilih

\subsection{Kondisi Eksisting LRK Terpilih}

Denah eksisting 3 LRK terpilih dapat dilihat pada Gambar 6, Gambar 7 dan Gambar 8. Kondisi pada LRK terpilih diperoleh dari survei lapangan, yang dilengkapi diagram tabrakan mengetahui letak dan tipe kecelakaan pada setiap lokasi yang ditinjau. Dari denah eksisting dan diagram tabrakan yang telah dibuat, dilanjutkan dengan membuat denah usulan penanganan pada 3 LRK prioritas seperti terlihat pada Gambar 12, Gambar 13 dan Gambar 14.

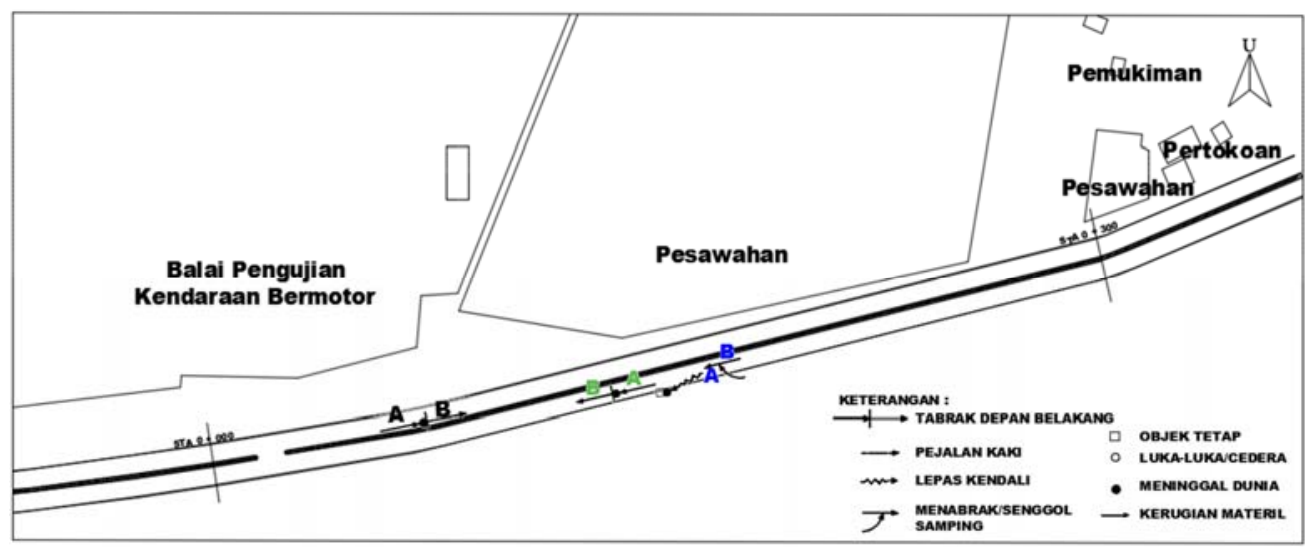

Gambar 6 Denah Eksisting LRK Terpilih 1: Jl. Sor GBLA 


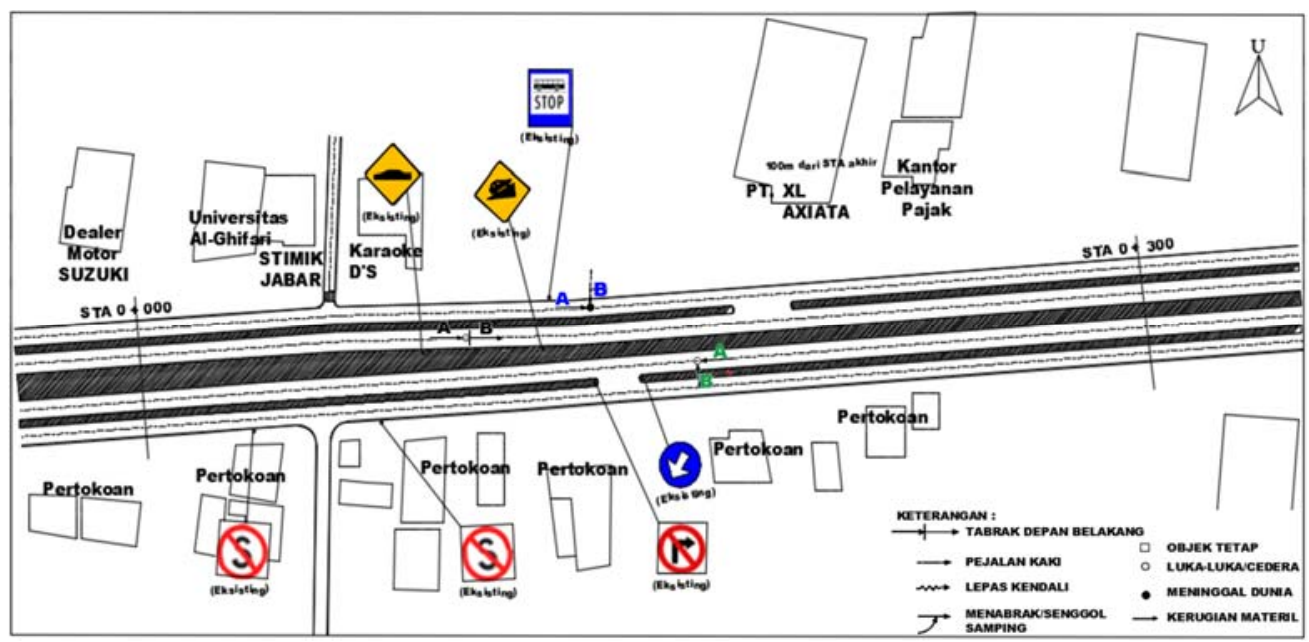

Gambar 7. Denah Eksisting LRK Terpilih 2: Jl. Soekarno Hatta (STIMIK Jabar)

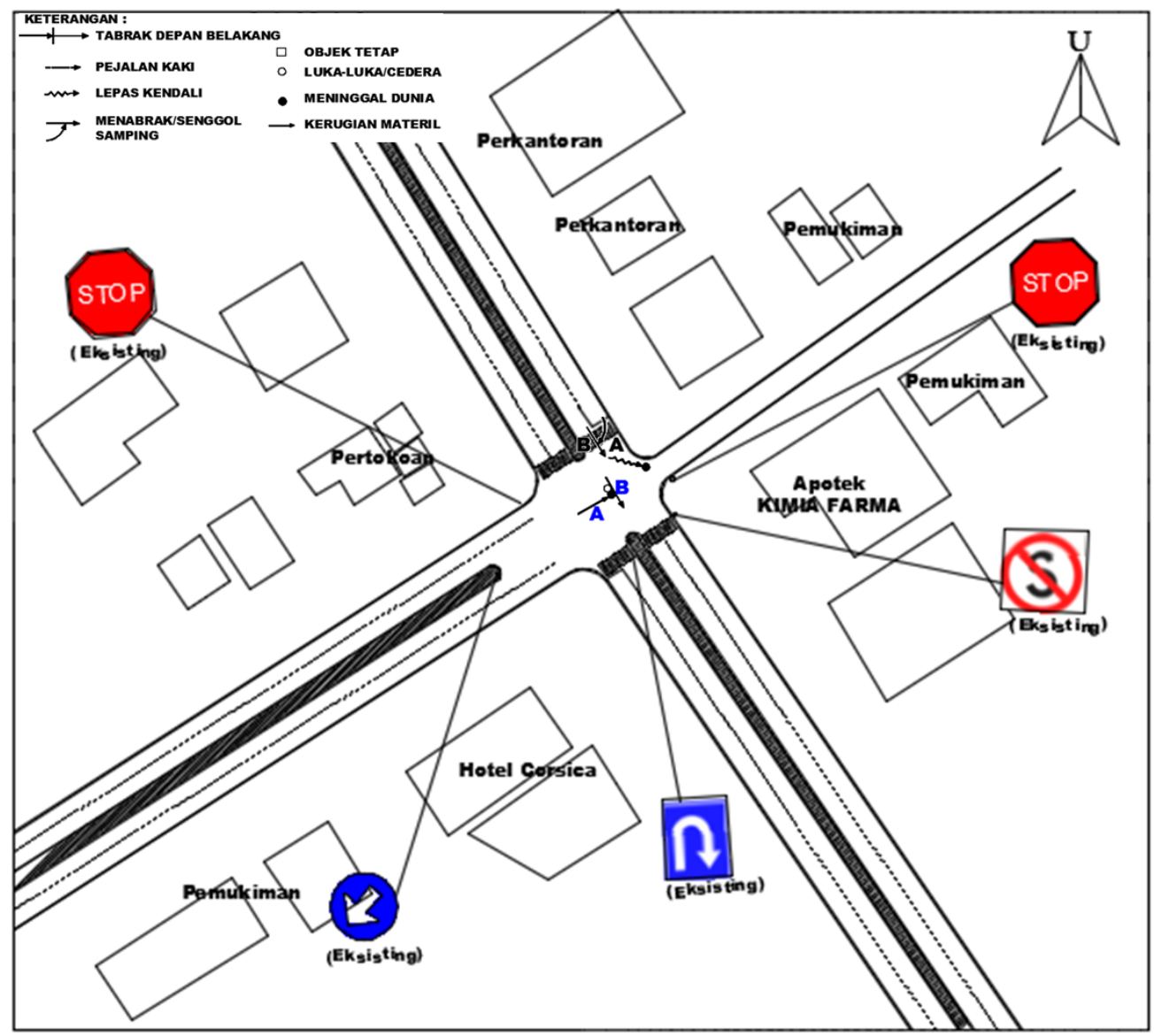

Gambar 8. Denah LRK Terpilih 3: Simpang Supratman-Ciliwung 
Tabel 2. Hasil Pengamatan 3 LRK Terpilih

\begin{tabular}{|c|c|c|c|}
\hline Hasil Pengamatan & LRK -1 & LRK - 2 & LRK - 3 \\
\hline Lokasi & Jl. Sor GBLA & Jl. Soekarno-Hatta & $\begin{array}{l}\text { Simpang Supratman- } \\
\text { Ciliwung }\end{array}$ \\
\hline Tipe Jalan & $4 / 2 \mathrm{D}$ & $8 / 2 \mathrm{D}$ & $\begin{array}{c}\text { simpang tak } \\
\text { bersinyal }\end{array}$ \\
\hline Lebar Jalan & $6,1 \mathrm{~m}$ & $31,8 \mathrm{~m}$ & $5-15 \mathrm{~m}$ \\
\hline Lebar Kerb & $1,85 \mathrm{~m}$ & $2,2 \mathrm{~m}$ & $2,3-4,4 \mathrm{~m}$ \\
\hline Kondisi Permukaan & Baik & Baik & Baik \\
\hline Marka Jalan & Tidak Ada & Ada & Sebagian \\
\hline Penerangan Jalan & Cukup & Baik & Kurang \\
\hline Tata guna lahan & Persawahan & Komersial & Komersial \\
\hline Kecepatan P85 & $71 \mathrm{~km} / \mathrm{jam}$ & $66 \mathrm{~km} / \mathrm{jam}$ & $41 \mathrm{~km} / \mathrm{jam}$ \\
\hline $\begin{array}{l}\text { Penggunaan helm } \\
\text { untuk sepeda motor }\end{array}$ & Kurang & Baik & Baik \\
\hline Foto Dokumentasi & & & \\
\hline
\end{tabular}

\subsection{Penyusunan Penanganan LRK Terpilih}

Dari denah eksisting dan diagram tabrakan yang telah dibuat di atas, dilanjutkan dengan membuat denah usulan penanganan pada 3 LRK terpilih. Desain Dapat dilihat pada Gambar 9, Gambar 10, dan Gambar 11.

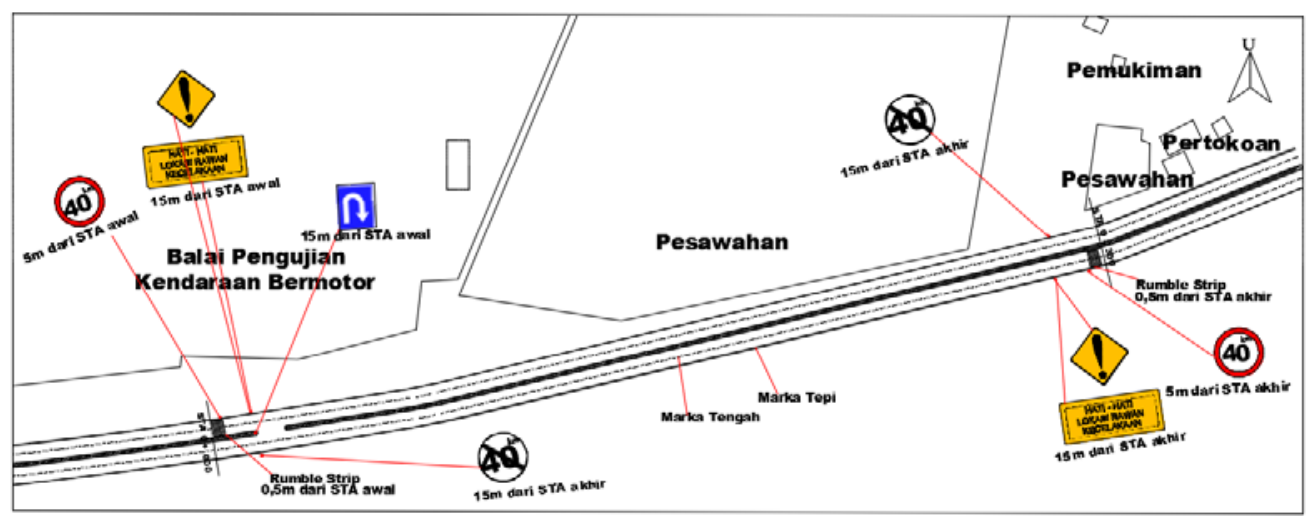

Gambar 9. Desain Penanganan LRK JI. Sor GBLA 


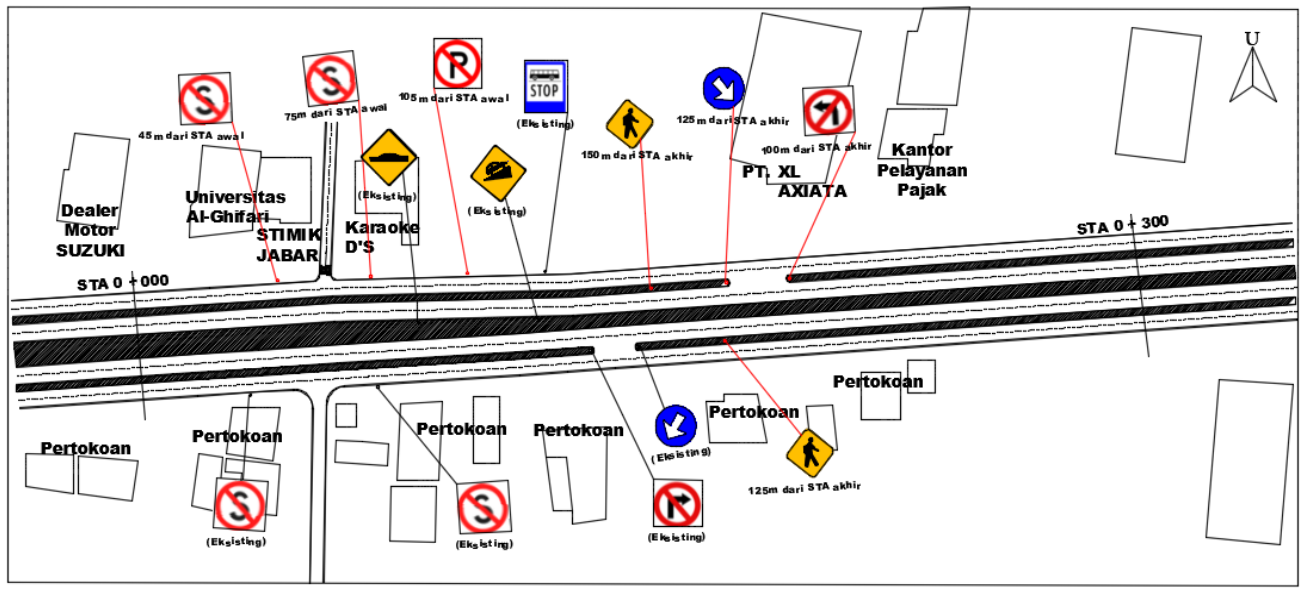

Gambar 10. Desain Penanganan LRK Jl. Soekarno Hatta

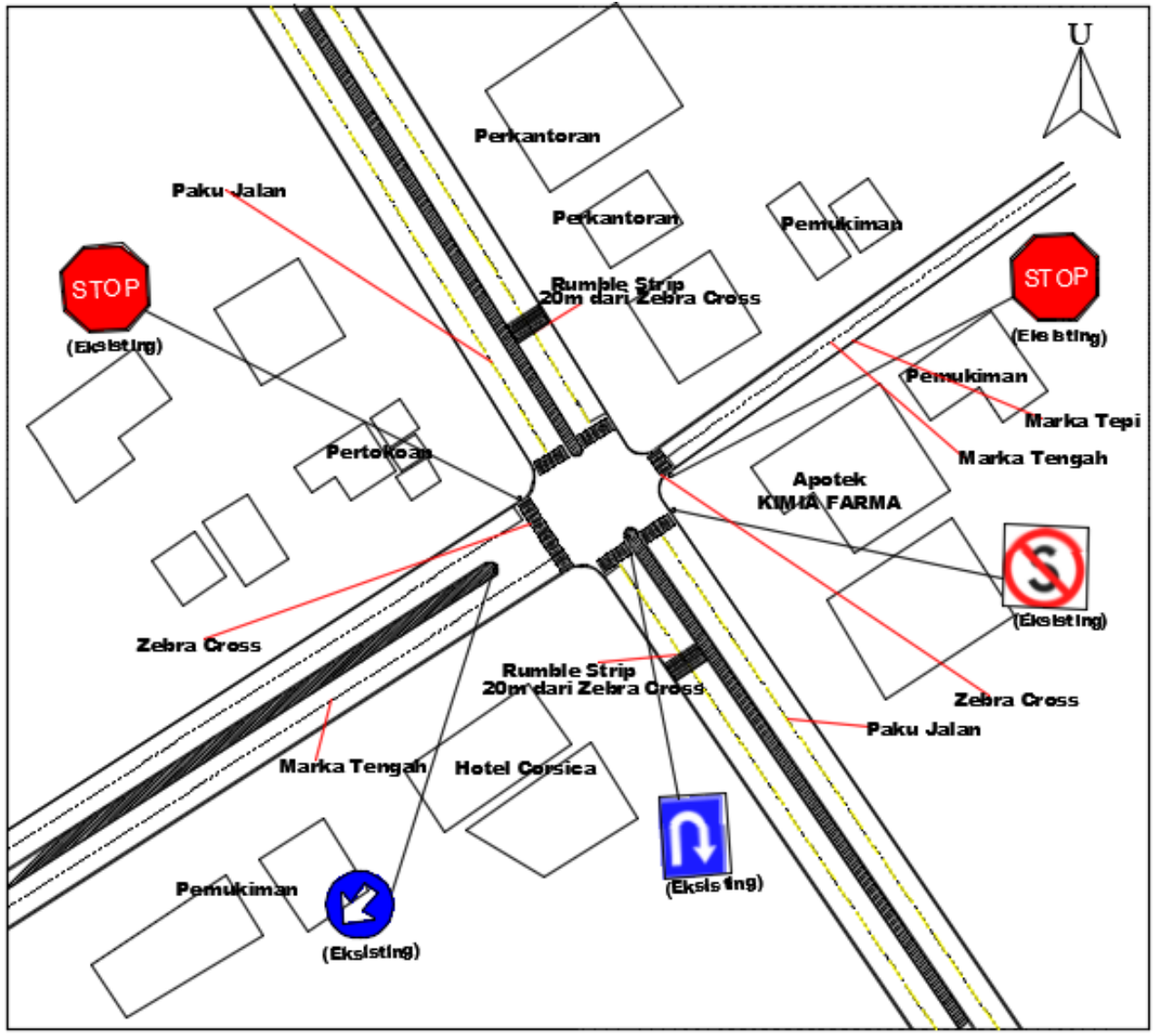

Gambar 11. Desain Penanganan LRK di Simpang Supratman-Ciliwung 
Penetapan penanganan LRK didasari juga dengan ketersediaan dana. Dilakukannya penanganan tersebut sebagai upaya mengurangi tingkat kecelakaan dan meningkatkan keselamatan jalan. Penanganan LRK terpilih di Jl. Sor GBLA meliputi:

1. Pemasangan rambu lalu lintas:

a. Peringatan dengan kata-kata "Hati-hati Lokasi Rawan Kecelakaan"

b. Larangan menjalankan kendaraan dengan kecepatan lebih dari $40 \mathrm{~km} / \mathrm{jaml}$

c. Petunjuk putar balik,

d. Batas akhir larangan melaju dengan kecepatan $40 \mathrm{~km} / \mathrm{jam}$,

2. Pemasangan pita penggaduh (rumble strip), dan

3. Pemasangan marka tengah dan tepi jalan.

Penanganan LRK terpilih di Jl. Soekarno-Hatta meliputi pemasangan rambu:
a. Larangan berhenti,
b. Larangan parkir,
c. Peringatan banyak lalu lintas pejalan kaki,
d. Perintah memasuki jalur yang ditunjukkan (kanan),
e. Larangan berbelok ke arah kiri.

Penanganan LRK terpilih di Simpang Supratman-Ciliwung meliputi:

1. Pemasangan paku jalan,

2. Pemasangan zebra-cross,

3. Pemasangan pita penggaduh (rumble strips), dan

4. Pemasangan marka tengah dan tepi jalan.

\section{KESIMPULAN}

Penelitian Studi Lokasi Rawan Kecelakaan di Kota Bandung menghasilkan beberapa temuan, antara lain:

1. Berdasarkan kriteria LRK, diperoleh 92 titik LRK di Kota Bandung.

2. Berdasarkan analisis AEK dan UCL terdapat 15 LRK prioritas di Kota Bandung.

3. Tiga LRK dipilih sebagai acuan survei lapangan dan penyusunan penanganan, yaitu:

a. J1. Sor GBLA $(\mathrm{AEK}=311)$,

b. Jl. Soekarno-Hatta $($ AEK $=216)$,

c. Simpang Supratman-Ciliwung $(\mathrm{AEK}=206)$.

4. Penanganan LRK meliputi pemasangan rambu lalu lintas, marka jalan, dan pita penggaduh di Jl. Sor GBLA, pemasangan rambu lalu lintas di Jl. Soekarno-Hatta, dan pemasangan paku jalan, zebra cross, pita penggaduh, dan marka jalan di Simpang Supratman-Ciliwung.

Studi Lokasi Rawan Kecelakaan di Kota Bandung (BARGESS) 


\section{UCAPAN TERIMA KASIH}

Penulis mengucapkan terima kasih kepada Universitas Kristen Maranatha, khususnya jurusan Teknik Sipil dan para dosen-dosen yang telah membimbing penyusunan penelitian ini, Polrestabes Bandung sebagai penyedia data kecelakaan, serta pihak-pihak lain yang telah membantu.

\section{DAFTAR PUSTAKA}

1. BPS Kota Bandung, 2018, Kota Bandung Dalam Angka 2018

2. Departemen Permukiman dan Parasarana Wilayah, 2004, Pedoman Penanganan Lokasi Rawan Kecelakaan Lalu Lintas Nomor Pd T-09-2004-B, Pusat Penelitian dan Pengembangan Prasarana Transportasi, Jakarta.

3. Kementerian Perhubungan, 2013, Peraturan Direktur Jenderal Perhubunagan Darat Nomor: SK.7234/AJ.401/2013, Petunjuk Teknis Perlengkapan Jalan.

4. Kementerian Perhubungan, 2014, Peraturan Menteri Perhubungan RI Nomor 34 tahun 2014, Marka Jalan.

5. Kementerian Perhubungan, 2014, Peraturan Peraturan Menteri Perhubungan RI Nomor 13 Tahun 2014, Rambu Lalu Lintas.

6. Korlantas Polri, 2018, Data Kecelakaan Lalu Lintas 2018, Integrated Road Safety Management System (IRSMS), Jakarta.

7. Polrestabes Bandung, 2019, Data Kecelakaan Lalu Lintas tahun 2018.

8. Susilo, B. H, 2016, Buku Panduan Praktis Keselamatan Lalu Lintas Jalan, Pusat Studi Transportasi Antar Disiplin Ilmu di Universitas Kristen Maranatha, Bandung.

9. Undang-Undang Republik Indonesia Nomor 22, 2009, Lalu Lintas dan Angkutan Jalan. 